\title{
THOMAS REID SOBRE CONCEPÇÃO, PERCEPÇÃO E RELAÇÃO MENTE-MŰNDO EXTERIOR
}

\section{THOMAS REID ON CONCEPTION, PERCEPTION, AND MIND-EXTERNAL WORLD RELATIONSHIP}

Roberto Hofmeister Pich*

RESUMO - A noção de "concepção" ocupa um lugar central na teoria do conhecimento perceptual de Thomas Reid, embora "concepção" possa ser estudada por si como uma fonte de conhecimento. Neste estudo, procura-se expor sistematicamente os vários contextos em que Reid aborda a fonte de conhecimento e o tipo de operação mental chamada "concepção". O objetivo é compreender um aspecto específico do desempenho da "concepção" na teoria reidiana da percepção, a saber, uma relação direta, não mediada por ideias, entre o sujeito cognoscente e o mundo exterior. Entender a operação de conceber, intrínseca à e constituinte da percepção, é um meio eficaz de compreender a natureza e o conteúdo do conhecimento perceptual. Nesse passo, considerações sobre a relação mente e mundo exterior, isto é, mente e mundo material precisam ser feitas.

PALAVRAS-CHAVE - Thomas Reid, concepção, percepção, relação mente e mundo material, percepção direta.

ABSTRACT - The notion of "conception" plays a central role in Thomas Reid's theory of perceptual knowledge, although "conception" might be studied for itself as a source of knowledge. In this study, we attempt to expose systematically the several contexts where Reid deals with the source of knowledge and the kind of mental operation called "conception". The purpose is to understand a specific aspect of the deliverances of "conception" in Reid's theory of perception, namely, a direct relationship, not mediated by ideas, between knowing subject and external world. To understand the operation of conceiving, which

* Doutor em Filosofia pela Universidade de Bonn, Alemanha. Professor de Filosofia na Pontifícia Universidade Católica do Rio Grande do Sul. <roberto.pich@pucrs.br>; <roberto.pich@pq.cnpq.br>.

\begin{tabular}{|l|l|l|l|l|l|}
\hline Veritas & Porto Alegre & v. 55 & n. 2 & maio/ago. 2010 & p. 144-175 \\
\hline
\end{tabular}


is intrinsic to and constitutive of perception, is an efficient way to comprehend the nature and content of perceptual knowledge. At this step, reflections on the relationship between mind and external world, that is, mind and material world, have to be made.

KEYWORDS - Thomas Reid, conception, perception, relationship between mind and material world, direct perception.

\section{Introdução: traços básicos}

Para o fundador da "filosofia do senso comum" escocesa no século 18, Thomas Reid, "conceber" é uma operação da mente, um modo de pensar específico do qual se está ou se pode estar consciente. Porque é uma operação da mente, "concepção" é uma ação, e essa só pode provir de algo que é "vivo" e "ativo"1. "Concepção" supõe um "poder no ente que [a] opera". Sendo ela ademais um poder "original" e "natural" (constituinte) da mente, não adquirido, ela pode ser chamada de "faculdade" da mente. Uma "concepção" como ato de conceber é uma "coisa na mente" porque esta é o seu sujeito em todo e qualquer indivíduo - um sentido básico da diferença entre coisas "interiores" e "exteriores" é a diferença entre ter a mente como sujeito e não a ter como sujeito ${ }^{2}$. Conceber uma coisa exterior é, de pronto, ter na mente uma operação cujo sujeito portador, pois, é a própria mente e cujo objeto é a coisa exterior. Reid não crê que a "concepção", como as demais operações, seja capaz de "definição estrita". O seu significado é obtenível apenas por reflexão atenta sobre a mente enquanto concebendo ${ }^{3}$.

Buscando um significado mais estrito de "concepção", já no Ensaio I, "Preliminar", dos extraordinários Essays on the Intellectual Powers of Man (EIP) de 1785, Reid nota que "conceber", "imaginar" e "apreender" são expressões para "simples apreensão". E qual é o específico da "concepção" como operação mental? Se a tríade perceber-lembrarestar-consciente está comprometida com a convicção da existência de um objeto, vê-se claramente que é possível conceber o que não teve e não tem existência no presente (cf. abaixo Seção 2). Ademais, conceberimaginar-apreender propriamente não implica juízo ou crença, mas há ali, não obstante isso, um ato mental. Na concepção em si, nada é afirmado ou negado, ela não é nem falsa nem verdadeira ${ }^{4}$. Ora, o uso filosófico do termo

1 Cf. Thomas Reid, Essays on the Intellectual Powers of Man [a partir daqui, EIP], I.i.1-2, p. 20-21.

2 Cf. EIP I.i.3-4, p. 21-22.

3 Cf. EIP I.i.5, p. 22.

4 Cf. EIP I.i.8, p. 24-25. 
"conceber", não o uso comum, pressupõe a análise da linguagem para evidenciar a diferença de sentidos do termo. Como "simples apreensão", uma concepção é seguida por um substantivo no caso acusativo, em que aquele significa "o objeto concebido" - tal como se fosse dito "Concebo uma árvore". Se "conceber" tem (ou tivesse) um uso linguístico que expressa juízo ou crença, a palavra conjugada vem (ou viria) seguida, na língua inglesa, pelo verbo no modo infinitivo - na língua portuguesa, por uma oração subordinada, como "Concebo que a árvore é verde". Quando "conceber" é utilizado no primeiro sentido - e a distinção entre o primeiro sentido e o segundo é evidente a todo aquele que reflete sobre a mente -, a coisa concebida só pode ser um termo simples ${ }^{5}$.

"Concepção", pois, como poder intelectual próprio, pode ser estudada por si mesma ${ }^{6}$. Isso será explorado nas Seções 2 e 3 deste ensaio. Essa investigação será conduzida, contudo, pelo interesse de elucidar o papel que a "concepção" exerce na teoria do conhecimento perceptual de Reid (Seção 1) e, ali mesmo, ainda mais especificamente, o caráter direto da percepção que a concepção ajuda a explicar, a saber, uma relação não mediada por ideias entre o sujeito cognoscente e o mundo exterior. Não entrará em apreço a aguda crítica de Reid à "teoria comum das ideias", em que cabe argumentar a favor da sua irrealidade e insuficiência metodológica ${ }^{7}$. Sem dúvida, entender a operação de conceber, intrínseca à e constituinte da percepção, é um meio eficaz de compreender a natureza do conhecimento perceptual, que tem como objeto uma coisa real do mundo exterior. Sobretudo, quer-se visualizar como, nessa relação direta, Reid entende que, sem a mediação de ideias, a mente e o mundo material exterior estão de fato vinculados (Seção 4 e Considerações finais). A base da investigação são os já aludidos Ensaios, em particular porque neles o objetivo da pesquisa ganha ênfase marcante ${ }^{8}$. Até o desenlace do estudo,

5 De todo modo, Reid reconhece que uma proposição pode ser apreendida ou concebida em seu significado sem a formação de um juízo de verdade ou falsidade. Cf. EIP I.i,8, p. 25.

6 Reid oferece uma extensa abordagem da concepção como fonte de conhecimento nos Ensaios IV e V - sobretudo no Ensaio IV - dos seus Essays on the Intellectual Powers of Man.

7 Cf., por exemplo, Yves Michaud, Reid's Attack on the Theory of Ideas: From a Reconsideration of Reid's Arguments to a Reassessment of the Theory of Ideas, in: Melvin Dalgarno and Eric Matthews (eds.), The Philosophy of Thomas Reid, p. 9-34; John Greco, Reid's Reply to the Skeptic, in: Terence Cuneo and René Van Woudenberg (eds.), The Cambridge Companion to Thomas Reid, p. 134-155. Cf. também Roger D. Gallie, Thomas Reid and 'The Way of Ideas', p. 21ss.

8 Um relato comparativo, mas com propósitos diferentes daqueles que aqui se lançam, entre "concepção" nos Inquiries into the Human Mind on the Principles of Common Sense (a partir daqui IHM) e os Essays, foi feito, por exemplo, por Keith Lehrer, Reid on Evidence and Conception, in: Malvin Dalgarno and Eric Matthews (eds.), The Philosophy of Thomas Reid, p. 123-139. 
a forma de exposição é conscientemente descritiva; buscou-se uma forma de relatar os termos da epistemologia de Reid em que as sugestões possíveis da relação entre sujeito e mundo material ganhassem contorno e a importância de uma resolução alternativa ao representacionalismo ${ }^{9}$ e ao materialismo ${ }^{10}$ fosse tanto mais constatada.

\section{Percepção e concepção}

Um passo importante na investigação da relação entre mente e mundo exterior está no fato de que toda percepção envolve concepção, mas nem toda concepção é aspecto constitutivo da percepção. A "concepção" que tem vez em "percepções" é tratada por Reid formalmente em EIP II.v. Sem dúvida, a consciência é um pressuposto autorizado para se saber da concepção e da percepção, mas, como já mostrado em outro estudo $^{11}$, o meio adequado para esse conhecimento é a atenção aos atos mentais imediatamente presentes e em realização e, em seguida, a reflexão cuidadosa sobre os mesmos. É a partir disso que Reid afirma que perceber um objeto externo envolve (i) a "concepção" ou "noção" do objeto, (ii) a convicção irresistível da sua existência presente e (iii) a crença imediata na sua existência ${ }^{12}$. O ponto característico ao qual se quer dar consideração particular, aqui, é o primeiro: (i) a concepção do objeto percebido ${ }^{13}$.

9 Tomo "representacionalismo", aqui, de forma suficientemente geral para a história da filosofia e, pois, para as suposições de Reid, a saber, como "a concepção, (...), de que os nossos dados-sensórios experimentados imediatamente, junto com as crenças posteriores às quais chegamos com base neles, constituem uma representação ou descrição de um reino independente de objetos materiais - um reino no qual, em geral, de acordo com o representacionalista, estamos justificados em crer como sendo verdadeiro"; cf. Laurence BonJour, Conhecimento do mundo exterior, in: Laurence BonJour e Ann Baker (eds.), Filosofia - Textos fundamentais comentados, p. 151; sem dúvida, esse entendimento de representacionalismo sempre está alerta à crítica de que qualquer relação causal entre algo além ou fora da experiência (o mundo material exterior independente) e a própria experiência (a percepção) é eventualmente incognoscível.

10 De forma simples, tomo "materialismo", aqui, como a convicção, advogada pelas ciências ou por outros domínios, segundo a qual tudo o que existe, ou seja, todos os objetos e todas as coisas designáveis no mundo, são, assim como os corpos físicos, compostos, sem exceção e em última análise, de partículas físicas elementares. Nesse sentido, oposições ou distinções como "material" e "mental" perdem o sentido.

11 Cf. Roberto Hofmeister Pich, Thomas Reid, o método de filosofar e a rejeição do ceticismo, op. cit., p. 243-275.

12 William P. Alston, Reid on Perception and Conception, in: Melvin Dalgarno and Eric Matthews (eds.), The Philosophy of Thomas Reid, p. 35, põe isso elegantemente: "To perceive a tree is for a conception of the tree and a belief in its present existence to occur in the mind without having been arrived at inferentially".

13 Cf. EIP II.v, p. 96-97. 
Toda concepção-em-percepção tem, pois, como de resto toda concepção ou noção, um objeto. Ela, nesse caso, é como que simultânea ao perceber, talvez só por natureza anterior ao perceber o objeto - que envolve, além disso, os aspectos (ii) e (iii). Reid afirma que a noção que se tem de um objeto, enquanto é também percebido, é comumente "mais clara e firme" do que a que se tem de um objeto que é só lembrado ou imaginado. Qual a razão disso? Aparentemente, Reid quer dizer que o objeto, nesse caso, é conhecido com mais determinação respectiva às suas propriedades primárias e secundárias, que são os dados típicos da concepção do objeto: algo com propriedades primárias e secundárias concebidas. Reid também admite que a noção-em-percepção aparece em graus: os sentidos fornecem uma noção do objeto que pode ser "mais ou menos clara, mais ou menos distinta, em todos os graus possíveis". O que Reid quer dizer com a tese de que a noção de objetos vem em graus? A que eles são respectivos ${ }^{14}$ ?

Ao que tudo indica, isso quer dizer que a clareza e a distinção dessas concepções é dependente das condições em que os objetos se apresentam aos sentidos e, por conseguinte, ao intelecto que apreende. Objetos ganham noção mais ou menos clara na dependência, por exemplo, da distância e da clareza do dia (ou de um momento do dia), no que tange ao desempenho natural dos sentidos (nesse caso, da visão em especial), ou se o objeto é apreendido com o auxílio ou sem o auxílio de algum instrumento. Em um sentido natural, parece haver uma graduação, que Reid não se esforça em estabelecer com muitos detalhes, que vai de um máximo a um mínimo de adequação ao desempenho do órgão, com respeito, por exemplo, à visão de um objeto à distância e em iluminação perfeitamente adequadas até a distância imprópria para a visão e a ausência completa de luz - valendo o mesmo semelhantemente aos objetos dos demais sentidos ${ }^{15}$.

Reid admite, sem dúvida, que o grau de clareza e distinção de noções ou concepções pode depender ainda de outro fator, a saber, a maior ou menor complexidade do objeto apreendido, que é ao menos em parte relacionada com a maior ou menor capacidade de concepção do sujeito. Pode haver de um mesmo objeto uma noção obtida por intermédio dos sentidos externos, mais simples e indiferenciada, como também uma mais "científica", que um ser humano experiente é capaz de realizar. Esse ser humano já atentou alguma vez - ou algumas vezes - para os atributos do objeto (ou de objetos semelhantes), as suas partes, as relações entre as partes e as relações das partes com o todo. Ao que parece, Reid tem

14 Cf. EIP II.v, p. 96.

15 Cf. EIP II.v, p. 96-97. 
em vista a operação mental chamada "conceber" que foi expandida e aperfeiçoada a partir de outros poderes da mente, a saber, o juízo, a percepção, a memória, a reflexão atenta e a própria concepção a modo de abstração de aspectos e o uso de noções para significar algo comum a muitos indivíduos. Em certo sentido, se uma concepção básica ou rudimentar a modo de consciência de um objeto exterior indiferenciado é anterior por natureza à percepção, e contudo coordenada a ela, concepções independentes e mais diferenciadas já pressupõem operações realizadas por outras faculdades da mente ${ }^{16}$. Assim, outros poderes da mente, que geram outras operações, ajudam a concepção a se tornar mais detalhada ou clara e distinta no que diz respeito ao todo complexo que é um objeto concebido quando da percepção original ${ }^{17}$.

Mas, quais são os objetos que, na percepção, são percebidos porque ou enquanto concebidos? Dito de outra forma: quais são os objetos que um percipiente concebe e nisso coloca-se em contato "direto", pela mente, com o mundo exterior? Reid não hesita em afirmar que os objetos da percepção, primeiramente, "são as várias qualidades dos corpos"18, motivo pelo qual se pode esperar um relato sobre qualidades primárias e secundárias do objeto material. Aqui, ele acompanha o relato de Locke: exemplos de qualidade primárias são "extensão", "divisibilidade", "figura", "movimento", "solidez", "dureza", " maciez" e "fluidez". Exemplos de qualidades secundárias são "som", "cor", "gosto", "odor", "calor" ou "frieza" ${ }^{19}$. Mas, qual é o fundamento real dessa distinção?

Esse fundamento real é obra dos sentidos: eles oferecem "noção direta" e "distinta das qualidades primárias" e ainda informam o que elas em si mesmas são. É assim que se pode ter "noção perfeitamente clara e distinta" de propriedades como "extensão", "divisibilidade", "figura", etc., ou outras propriedades que dependem do tato, como "solidez", "maciez", "fluidez" de um corpo, etc. Em resumo: "É evidente, portanto,

16 Nesse aspecto, estou de acordo com Ryan Nichols, Thomas Reid's Theory of Perception, 44-46.

17 Cf. EIP II.v, p. 97: “(...)" the notion which we get of an object, merely by our external sense, ought not be confounded with that more scientific notion which a man, come to the years of understanding, may have of the same object, by attending to its various attributes, or to its various parts, and their relation to each other, and the whole. (...). The child sees the Jack [of a roasting meat] and every part of it as well as the man: The child, therefore, has all the notion of it which sight gives; whatever there is more in the notion which the man forms of it, must be derived from other powers of the mind, which may afterwards be explained. This observation is made here only, that we may not confound the operations of different powers of the mind, which, by being always conjoined after we grow up to understanding, are apt to pass for one and the same". Cf. também Keith Lehrer, Thomas Reid, p. 126ss., 130ss.

18 Cf. EIP II.xvii, p. 200-201.

19 Cf. EIP II.xvii, p. 201. 
que das qualidades primárias temos uma noção clara e distinta; sabemos o que elas são, ainda que possamos estar ignorantes das suas causas"20. Porém, o que Reid tem em vista ao afirmar que é "direta" a noção clara e distinta que se tem de "qualidades primárias"? Em contraste com uma "noção relativa", que não é da coisa, "mas somente de alguma relação que ela tem com alguma outra coisa", explica-se o que é uma noção direta tomando a "gravidade" como exemplo. A gravidade é às vezes "a tendência do corpo à terra", às vezes é "a causa mesma" dessa tendência. No primeiro caso, trata-se de uma noção "direta e distinta". Mas, da causa homônima dessa tendência tem-se noção só por reflexão. Como ela é caracterizável? Pensa-se nela como a "causa desconhecida" de um "efeito conhecido", a saber, a tendência do corpo à terra. Essa é uma "noção relativa" e, para Reid, obscura, pois ela não fornece "nenhuma concepção do que a coisa é", mas fornece apenas concepção da relação que a coisa, a causa, tem com outra coisa, o efeito conhecido. Esse tipo de relação é suficiente para que se tenha uma noção relativa de algo. Se é verdade que há muitos objetos dos quais as faculdades humanas só podem fornecer uma noção relativa, não é relativa aquela noção que se tem das qualidades primárias: delas o sujeito cognoscente humano pode saber o que são em si mesmas ${ }^{21}$.

Em contrapartida, os sentidos só conseguem oferecer uma "noção relativa e obscura" das qualidades secundárias - de modo algum o que elas são em si mesmas. Os sentidos "nos informam somente que elas são qualidades que nos afetam de certa maneira" ou "produzem em nós certa sensação"22. Um exemplo disso é a qualidade em uma rosa que é chamada de "cheiro". Reid afirma que, por reflexão, pode-se descobrir a "noção distinta da sensação" que a rosa produz na mente. Mas, na rosa mesma não há nada de semelhante a essa sensação. Há por certo uma qualidade na rosa que "ocasiona" no sujeito a sensação, mas, pelo recurso empírico ou sensório, não se tem informação sobre essa qualidade. Por aquele recurso, sabe-se que "o cheiro na rosa é uma qualidade desconhecida", e essa deve ser a causa do bem conhecido cheiro da rosa. Tal qualidade desconhecida tem uma relação com a sensação "com a qual a natureza a conectou". O "cheiro da rosa" apreendido pelo olfato é, pois, uma "noção relativa": um "arranjo" (minha expressão) típico existente na coisa, a partir de qualidades físicas intrínsecas que nela se encontram, ligada a ou apta a gerar uma sensação natural geral no sujeito

20 Cf. EIP II.xvii, p. 201.

21 Cf. EIP II.xvii, p. 201-202.

22 Cf. EIP II.xvii, p. 201-202. Cf. sobre isso Jennifer McKitrick, Reid's Foundation for the Primary/Secondary Quality Distinction, in: The Philosophical Quarterly, p. 487-488. 
sentiente ${ }^{23}$. Qualidades secundárias são "causas desconhecidas" de sensações familiares.

Na base disso, Reid está plenamente convencido, como questão de fato e obtida por reflexão atenta, de que o fundamento para distinguir qualidades primárias e secundárias é real. A propósito, é uma importante conquista da filosofia moderna a percepção de que não há motivo por que acreditar que uma qualidade secundária se assemelha a qualquer sensação a que elas, nos entes sentientes, dão ocasião: os "eflúvios da rosa" não se assemelham à sensação do cheiro da rosa. Como visto, qualidades primárias são rigorosamente distinguidas de sensações ou "sentimentos" de entes sentientes como sujeitos - e que são virtualmente sempre individuais e diferentes, embora possam ser semelhantes. Qualidades primárias como "figura" e "divisibilidade" não pressupõem um sujeito sentiente, mas só "um sujeito [exterior] que tem figura e é divisível". As qualidades primárias citadas, como as demais, não são alvo de opiniões distintas; a sua natureza é a todos "manifesta", mesmo podendo haver disputa sobre as suas causas ${ }^{24}$.

Com efeito, Reid admite que há muitos outros objetos imediatos da percepção, além das qualidades primárias e secundárias dos corpos, como apresentadas. Esses incluem (i) "certos estados ou condições dos nossos próprios corpos" (em realidade, "desordens" sentidas no corpo), (ii) "poderes ou forças mecânicas", (iii) "poderes químicos", (iv) "poderes ou virtudes médicas", (v) "poderes vegetais e animais", etc. ${ }^{25}$ - de fato, ao final de EIP II.xviii, Reid segue classificando as qualidades primárias somente como "manifestas" e todas as demais qualidades e/ ou objetos imediatos como "ocultos", ou seja, de manifesta existência aos sentidos, mas de oculta natureza ${ }^{26}$. Mais importante, sem dúvida, é a consideração final de que qualidades conhecidas como objetos imediatos de percepções têm de ter um sujeito, um "sujeito de qualidades

${ }^{23}$ Cf. EIP II.xvii, p. 202. Nesse aspecto, estou de acordo com o relato de James Van Cleve, Reid's Theory of Perception, in: Terence Cuneo and René Van Woudenberg (eds.), The Cambridge Companion to Thomas Reid, p. 110-111. De todo modo, não estou expressando apoio maior ou menor à tese de que a teoria reidiana de propriedades secundárias favorece o "disposicionalismo" ou então a acepção das "propriedades de base física" independentes da mente ou de esquemas a modo de dependência de resposta pelo sujeito: o debate permanence; cf. por exemplo, Ryan Nichols, op. cit., 171-177.

${ }^{24}$ Cf. EIP II.xvii, p. 202-203. Sobre a exatidão e o caráter inequívoco das qualidades primárias, cf. ainda EIP II.xvii, p. 203: "As qualidades primárias são os objetos das ciências matemáticas; e o caráter distinto das nossas noções delas nos capacita a raciocinar demonstrativamente sobre elas em grande medida. As suas várias modificações são precisamente definidas na imaginação, e a partir daí capazes de serem comparadas, bem como as suas relações determinadas com precisão e certeza".

${ }^{25}$ Cf. EIP II.xviii, p. 211ss.

26 Cf. EIP II.xviii, p. 217. 
sensíveis", ao qual se pode chamar de "matéria", "substância material" e "corpo". Por embaraçosa que seja essa noção de "sujeito" material, Reid admite que é uma espécie de lei da natureza ter cognições em que qualidades são conhecidas e entendidas como qualidades de alguma coisa que não é uma qualidade, mas cuja natureza ao final permanece velada $^{27}$. Essa situação natural sobre o objeto imediato das percepções é bem resumida assim:

\begin{abstract}
Portanto, parece ser um juízo da natureza que as coisas imediatamente percebidas são qualidades, que devem pertencer a um sujeito, e toda a informação que os nossos sentidos nos dão sobre esse sujeito é que ele é aquilo ao que pertencem tais qualidades. A partir disso, é evidente que a nossa noção de corpo ou matéria, como distinto das suas qualidades, é uma noção relativa; e receio que isso deva sempre permanecer obscuro, até que os homens tenham outras faculdades ${ }^{28}$.
\end{abstract}

Sem dúvida, a relação entre mente e mundo exterior material que a concepção, por um sujeito percipiente, ajuda a entender é uma relação da mente com um objeto existente enquanto existente (e presente). É uma relação direta com algo que possui propriedades primárias e secundárias e, ademais, é ou pode ser concebido na mesma situação sob aspectos gerais a modo de expressões universais em atos mentais ${ }^{29}$. A relação direta entre mente e mundo exterior material pode ocorrer tanto na concepção como na percepção (envolvendo, nesse caso, a concepção de um sujeito percipiente). Para ambos os casos, é útil enfatizar a segunda característica da percepção segundo Reid, a saber, que toda percepção (que inclui a concepção do objeto exterior) envolve a convicção da existência do objeto percebido - em que o "objeto percebido" nada mais é que o objeto concebido, com o acompanhamento de uma sensação, da qual se está consciente, adicionando-se a isso a geração de um juízo de existência presente sobre o objeto ${ }^{30}$. Isso pertence à natureza cognitiva humana, quando o poder de perceber está adequadamente em operação:

27 Cf. EIP II.xix, p. 217-218. Cf. Keith Lehrer, Thomas Reid, p. 102-105.

${ }^{28}$ Cf. EIP II.xix, p. 218-219.

29 Como ainda será referido, abaixo, se a concepção do objeto exterior é primitivamente de um conjunto individual de qualidades primárias e secundárias, indiferenciadas, de algo, a concepção pode passar a ser a abstração de ou atenção direcionada a qualidades individuais e, depois disso, a concepção geral ou universal em razão de utilidade e comunicação; cf. Keith Lehrer, Thomas Reid, p. 126-127. Cf. também Nicholas Wolterstorff, Thomas Reid and the Story of Epistemology, p. 9-22.

30 Sobre como esses elementos da percepção podem e devem ser corretamente esquematizados, para bem compreender a percepção "direta" sugerida por Thomas Reid, cf., por exemplo, James Van Cleve, Reid's Theory of Perception, in: Terence Cuneo and René Van Woudenberg (eds.), op. cit., p. 114ss. 
a crença perceptual assim configurada é irresistível. Isso vem a ser o caso quando o objeto chega aos sentidos com clareza e distinção, de modo que por natureza será gerada crença perceptual de existência com semelhante força e firmeza. Perceber, como um julgar existencial, vem também em graus, e isso responde ao grau de clareza e distinção com que a mente, com o uso dos sentidos externos, concebe algo existente ${ }^{31}$.

Assim, pois, há um sentido em que o contato com o mundo exterior, na percepção, nada mais é que a concepção pela mente de um objeto existente, em regra acompanhada de sensação, respectiva ao uso dos órgãos sensórios - que sofrem a impressão dos objetos do mundo exterior -, e com a realização de um juízo perceptual de existência. Essa crença, além disso, é básica ou imediata: ela não se deve a nenhum tipo de raciocínio ou argumentação, e a sua verdade evidente não é devida inferencialmente a nenhuma outra proposição e a nenhum outro princípio $^{32}$. A confiança nos sentidos para se obter uma crença verdadeira, imediata e evidente sobre o mundo exterior existente e presente está garantida pelo caráter naturalmente não falacioso das operações mentais humanas, e isso equivale a um primeiro princípio do senso comum ${ }^{33}$ ou tomado por garantido ${ }^{34}$. Um juízo perceptual tem verdade evidente sobre o seu objeto enquanto tipo de operação mental, e a origem definitiva de sua evidência é um princípio primeiro do senso comum sobre a própria percepção. Esse mesmo não é, para Reid, uma proposição da qual a outra é derivada, mas um princípio constitutivo - como semelhantemente o são outros princípios do senso comum respectivamente às demais operações mentais - daquilo que é o desempenho natural apropriado (não falacioso) do tipo específico de conhecimento que se convenciona

31 Cf. EIP II.v, p. 97.

32 Cf. EIP II.v, p. 96, 99ss.; EIP II.xx, p. 226ss.

${ }^{33}$ Cf. Keith Lehrer, Thomas Reid, p. 162-163, que chama esse princípio (cf. a nota seguinte) de "metaprincípio", o mais importante primeiro princípio e concernente a todas as faculdades humanas.

${ }^{34}$ Cf. EIP II.v, p. 100; cf. também I.ii, p. 39-47. Cf. VI.v,7, p. 480: “Outro primeiro princípio [das verdades contingentes] é Que as faculdades naturais, pelas quais distinguimos a verdade do erro, não são falaciosas". De fato, o entendimento do papel epistêmico dos "primeiros princípios do senso comum" em Reid é um tópico à parte, sobretudo se admitidas duas linhas de interpretação a partir dos seus textos, a saber, entendê-los como (a) primeiros princípios do raciocínio humano e/ou como (b) princípios ou regras tomadas por garantidas nas práticas cognitivas e doxásticas; cf. Nicholas Wolterstorff, Reid on Common Sense, in: Terence Cuneo and René Van Woudenberg (eds.), The Cambridge Companion to Thomas Reid, p. 80ss. Parece certo, porém, que os primeiros princípios do senso comum não operam como premissas para inferências, mas expressam a base constitutiva da conduta racional da qual toda pretensão cognitivo-epistêmica tem de partir. Cf. também Dennis Charles Holt, The Defense of Common Sense in Reid and Moore, in: Melvin Dalgarno and Eric Matthews (eds.), The Philosophy of Thomas Reid, p. 150-155. 
chamar de "percepção"35. Negar-se a admitir esse cenário acerca da natureza da percepção e acerca do que legitimamente esperar, no que tange ao conhecimento do mundo exterior, fica próximo a um insulto, tão grande quanto afirmar que é possível que se tenha outra conduta racional - isso, dada a constituição mental do ser humano, ninguém consegue efetivamente ter e tampouco coerentemente propor ${ }^{36}$.

Os pontos acima tornam explícito que a pergunta pela relação da mente com o mundo exterior material ocorre basicamente através da concepção de um objeto exterior e da percepção de um objeto exterior. É claro que o fato de a percepção incluir um relato sobre a concepção não deve levar à conclusão de que a percepção não é uma fonte básica, uma operação mental de desempenho cognitivo independente e, no caso, epistêmico. Toda percepção inclui concepção do objeto exterior como envolve juízo sobre o objeto exterior. A percepção, pois, pode ser vista como complexa, porque engloba desempenhos cognitivos que podem acontecer separadamente; isso, porém, não implica uma composição, porque o desempenho da percepção é único: especificamente o juízo perceptual. Ela envolve, contudo, uma forma da concepção, a do objeto exterior material, que, em comum com o relato da mera concepção de objetos externo ${ }^{37}$, é o locus da análise de como a mente tem em absoluto relação com o mundo exterior. Para esse propósito, a mera concepção do objeto exterior e a concepção desse objeto por um sujeito percipiente se prestam ao mesmo propósito e exigem a mesma fundamentação. De resto, é uma questão difícil posicionar-se sobre a tese de que, na maioria dos casos, concepções de objetos exteriores geram ou associam-se à geração de juízos perceptuais, seja se o mecanismo da percepção procede de maneira espontânea ou com intenção.

Aqui, uma observação geral sobre a teoria da concepção, sobretudo da concepção como ingrediente de percepções, com um olhar para problemas de interpretação na pesquisa, faz-se oportuna. Segundo a análise de textos empreendida, não considero preciso comparar a "concepção" reidiana, mesmo aquela em percepções primárias e originárias, simplesmente com "intuições kantianas", mera "consciência" ou "apontamento mental" da presença de algo, anteriores à conceitualização em juízos de experiência ${ }^{38}$,

35 Cf. EIP II.v, p. 100. Cf. também VI.v, p. 476: “Outro primeiro princípio é ‘Que existem de fato aquelas coisas que percebemos distintamente pelos nossos sentidos, e elas são o que percebemos que elas sejam'".

36 Cf. EIP II.v, p. 100-101. Cf. também EIP II.xx, p. 231, 233.

37 Afinal, cf. abaixo, a concepção obviamente não tem como objeto somente ou necessariamente um objeto material exterior.

38 Cf. James Van Cleve, Reid's Theory of Perception, in: Terence Cuneo and René Van Woudenberg (eds.), op. cit., p. 104. 
ou com "apreensões diretas" ou "acquaintances" a modo de Russell - não descritivo-conceituais, portanto ${ }^{39}$. Por certo, em um sentido fundamental, concepções em percepções são "conceitualizações" muito primárias a modo intuitivo, com pouca ou nenhuma diferenciação do objeto em aspectos $^{40}$ - a linguagem de Reid, desde o início, tende a falar de alguma forma de conceitualização de qualidades e sujeito de qualidades. Ao mesmo tempo, nada parece obstar que, expandida ou aperfeiçoada a concepção, concepções conceitualmente mais elaboradas apareçam em percepções - as concepções claras e distintas que passaram pela abstração de partes qualitativas individuais de objetos e pelo uso predicativo das mesmas. Acredito, ademais, que esse sentido é coerente com o sentido de "apreensão simples" na tradição antecessora a Reid, mesmo a escolástica, onde a operação mental respectiva tinha sentido "conceitual" pré-judicativo.

De todo modo, para que a abordagem de Reid sobre a relação mente e mundo material fique esclarecida, faz-se necessário expor mais detidamente o que é a concepção como operação mental. O conteúdo e a possibilidade da concepção ficarão tanto mais claros.

\section{Concepção ou noção é só um ato mental}

O propósito de investigação tem de passar pelo Ensaio IV, cujos capítulos iniciais são voltados, em sentidos diferentes, à definição mesma da concepção e a uma crítica geral a teorias equivocadas sobre ela. A considerar são ainda passagens diversas do Ensaio II, em que Reid, disputando com filósofos modernos e oferecendo finezas de análise linguística, detecta o que pode ser o conteúdo e o estatuto mental da concepção-noção.

Os lógicos chamam a concepção e o ter a noção de uma coisa de "apreensão simples", afirma Reid em EIP IV.i. Em realidade, é a isso que Reid quer reduzir o que vem a ser o "ter a ideia de uma coisa", a saber, a um modo próprio de conceber e ter noção de algo, em especial quando da percepção. Já foi dito que a apreensão simples não envolve nem um juízo nem uma crença. De todo modo, definir "concepção" como "apreensão simples" não é oferecer uma definição lógica, pois aquele é só um nome ou uma descrição para uma operação simples da mente,

39 Cf. Nicholas Wolterstorff, Thomas Reid and the Story of Epistemology, p. 11, 19ss.

40 Creio que isso está admitido na interpretação de Keith Lehrer, Thomas Reid, p. 189197. Também é admitido por Roger D. Gallie, Thomas Reid: Ethics, Aesthetics and the Anatomy of the Self, p. 45-61 (em especial, 58-59), com um apelo a algum aspecto mental de "fontes inatas [geradoras] de concepção". 
e operações simples da mente não são passíveis de definição lógica. A "noção distinta" delas só é conquistada por atenção ${ }^{41}$.

Ganhar uma noção distinta da concepção consiste em "explicar algumas das suas propriedades", apontando em especial para equívocos que teorias e filósofos adotaram sobre ela. Em primeiro lugar, a concepção é um ingrediente de toda operação mental: para crer perceptualmente, para lembrar, para raciocinar, para exercer qualquer poder ativo (mesmo aqueles que não são propriamente intelectuais), a concepção é uma condição necessária ${ }^{42}$. Ainda assim, a concepção pode encontrar-se "nua", em si mesma, e aqui ela é a "apreensão simples" ou "a mera concepção de uma coisa". Em segundo lugar, como apontado acima (cf. Introdução), na "mera concepção", não há nem verdade nem falsidade, qualidades que só podem pertencer a juízos e/ou proposições ${ }^{43}$.

No Ensaio IV, Reid retoma timidamente uma tese em que insistira de forma decisiva nos capítulos do Ensaio II. É importante notar, nesse passo, que o significado filosófico de "ideia" deve ser tornado plenamente equivalente e mesmo substituído pelo significado de "concepção" como operação mental. Afinal, ao atentar para a mente, um sujeito cognoscente encontra concepções como atos, e não ideias como meios representativos entre o sujeito e o objeto do ato mental, ideias essas que serviriam a cada vez como a síntese ou o ponto de tangência entre o sujeito e o mundo material exterior. Em suas discussões com Locke, Reid reiteradamente lembra que, ao fazer uso das expressões "ideia", "ideia que se tem" ou do "ter uma ideia", há que se diferenciar um sentido filosófico (e corrompido) e um sentido popular (e, no caso, acertado) das mesmas. Ora, é o sentido popular ou respectivo ao vulgo que lhe interessa, isto é, aquele segundo o qual "ter uma ideia" de alguma coisa significa "pensar" nessa alguma coisa. Além disso, de maneira geral, os seres humanos adultos (e sãos) não fazem confusão ou, ao menos, são efetivamente capazes de distinguir as diferentes operações mentais como tais, como, por exemplo, conceber e perceber, ter memória de algo e imaginar algo ${ }^{44}$.

Reid afirma, em terceiro lugar, que o entendimento do poder de conceber objetos está fortemente ligado à analogia entre a concepção e a "pintura ou outras artes plásticas". As linguagens revelam essa ênfase analógica, como se concepção fosse um poder para formar "imagens dos objetos do pensamento". Contudo, a analogia pode, é claro, induzir ao erro, caso se entenda o sentido "figurativo" como "primitivo". Ora, dado

${ }^{41}$ Cf. EIP IV.i, p. 295. Cf. Keith Lehrer, Thomas Reid, p. 127s.

${ }^{42}$ Cf. EIP IV.i, p. 296s.

43 Cf. EIP IV.i, p. 296-297.

${ }_{44}$ Cf. EIP IV.i, p. 297-299. 
que é uma analogia, há que se notar dessemelhanças e semelhanças entre conceber e, diga-se, "figurar" 45 . Ora, se alguém pinta, o trabalho feito (por exemplo, o "quadro") permanece, mesmo se a ação cessar, sendo o efeito algo diferente da ação de pintar (a causa $)^{46}$. Além disso, antes de a arte ser produzida, o quadro foi concebido na mente do pintor. Essa pré-concepção é "um ato da mente" ou "um tipo de pensamento". Mas, como se pode falar de causa e efeito no ato da mente que é conceber? Central é que "conceber" é um ato imanente da mente: ele não produz nada além de si mesmo. Por sua vez, "pintar" é um ato transitivo, produz um efeito, a pintura, diferente da ação de pintar. Justamente nesse ponto, pode-se perceber que o que se pensaria ser uma imagem (uma ideia em sentido pictórico) na mente nada mais é - isto é, a concepção mesma nada mais é - que "o ato ou a operação da mente" ao conceber determinada imagem ${ }^{47}$.

Com apelo ao senso comum, Reid pode agora dizer que conceber uma coisa é, por analogia, "ter uma imagem dela na mente", mas de tal modo que a imagem na mente (i) não é o "objeto da concepção" nem é (ii) um "efeito produzido pela concepção como uma causa", antes ela mesma, a saber, o ter ou o ato de ter uma imagem na mente, é a concepção. Conceber é um modo de pensar; dizendo isso em uma figura de linguagem, a concepção é "uma imagem [na mente] da coisa concebida". Sem dúvida, "imagem na mente" é uma expressão metafórica, pois sabe-se apenas que na mente há pensamento, e dizer que há ali uma imagem é uma expressão figurativa ${ }^{48}$. Enquanto mantém o sentido analógico útil dessa forma de expressão, Reid rejeita a opinião de que essa "imagem na mente" seja real, no sentido de ser "o objeto imediato da concepção" e, ao mesmo tempo, outra coisa que o ato de conceber uma imagem. O senso comum, insiste-se, revela que "concepção de uma coisa" e "imagem de uma coisa na mente" são somente duas expressões que significam uma e a mesma coisa, a saber, o ato mental de conceber algo ${ }^{49}$ : no ato mental, não há o ato mais um objeto mental desse ato; há o ato somente. Se uma análise dos elementos lógico-metafísicos da concepção pode ser feita, revela-se que ela pressupõe o sujeito de atos mentais e $o$ ato mental. Contém ela ainda algo mais?

45 Cf. EIP IV.i, p. 299. Cf. Keith Lehrer, Thomas Reid, p. 128-129.

${ }^{46}$ Cf. EIP IV.i, p. 300.

47 Cf. EIP IV.i, p. 300. Cf. Keith Lehrer, Thomas Reid, p. 128.

48 Cf. EIP IV.i, p. 300-301.

49 Cf. EIP IV.i, p. 300-301. Em outros contextos, Reid também admite que, metafórica ou analogicamente, pode-se chamar uma concepção distinta de algum objeto de "imagem" do objeto na mente, desde que "imagem" seja o mesmo que o ato de conceber um objeto, jamais ela mesma o objeto mental imediato da concepção, representante do objeto exterior. Cf., por exemplo, EIP II.xiv, p. 184. 
A concepção guarda outra analogia também com as "diferentes obras do pintor", que, por sua vez, faz pinturas (i) "imaginárias" ou (ii') a partir do que outros pintaram, ou ainda, é claro, (ii") "a partir da vida", de "objetos reais da arte ou da natureza". Essa analogia serve para dizer segundo quais tipos de objetos as concepções são divididas. (i) Há concepções que são feitas pela imaginação, não são "cópias" de um original, "mas são elas mesmas originais", tal que o seu objeto são "criaturas da imaginação", que jamais existiram ${ }^{50}$. (ii) Há, além disso, concepções que são tal como cópias, dado que têm "original" ou "arquétipo" ao qual se referem e com o qual concordam. Na medida mesma dessa relação, Reid diz que tais concepções são verdadeiras ou falsas, e elas admitem dois tipos. Um deles (ii") tem "imagens tiradas da vida" como analogia; assim, se a cidade de Londres é uma coisa que existe, a concepção que alguém tem dela é verdadeira se tem concordância com tal "coisa da vida", com o "original" tal como ele realmente é, ao menos até certo nível de apreensão. Reid fala aqui de "coisas individuais que realmente existem" e foram feitas por Deus (ou pela natureza), ou ainda pelo ser humano, de tal forma que somente quem as fez sabe de sua natureza inteira; as concepções humanas sobre esses indivíduos são limitadas, mas justas até certo ponto ${ }^{51}$.

(ii') O outro tipo de concepção-cópia se assemelha à cópia que um pintor faz tendo como base pinturas já feitas. Reid localiza aqui os "universais", aquilo que pertence ou pode pertencer a muitos indivíduos. Nesse caso, fala-se de concepções a modo de tipos ou espécies de coisas, como "ser humano", "sabedoria", "igualdade", etc. Sobre sua origem e sua verdade e falsidade, pode-se dizer brevemente: a primeira é o significado, a concepção ou a noção que as pessoas linguisticamente competentes afixam às palavras (gerais) correspondentes, a segunda é a concordância e discordância que as concepções formadas têm para com os significados comuns afixados, considerados como padrões ${ }^{52}$. Em resumo, há três tipos de concepções, divididas no que concerne ao seu objeto: (1) de "coisas individuais" existentes no mundo (feito por Deus) - e sob essa rubrica parece justo considerar tanto objetos particulares como todos (mais ou menos) "indiferenciados" como aspectos particulares abstraídos de objetos particulares ${ }^{53}$-, (2) do "significado das palavras gerais" 54 e (3) de coisas criadas pela imaginação ${ }^{55}$. Para o tópico deste ensaio,

50 Cf. EIP IV.i, p. 301.

51 Cf. EIP IV.i, p. 301-302.

52 Cf. EIP IV.i, p. 302-304. Cf. Keith Lehrer, Thomas Reid, p. 129-130.

53 Isso parece valer em especial para os Ensaios; cf. Keith Lehrer, op, cit., p. 190ss.

${ }^{54}$ Cf. também Nicholas Wolterstorff, Thomas Reid and the Story of Epistemology, p. 13-22.

55 Cf. EIP IV.i, p. 305ss. 
o primeiro tipo de concepção, sobretudo a concepção de todos (mais ou menos) "indiferenciados", o tipo que precipuamente tem lugar em casos de percepções, é o mais relevante, de maneira que ocupa de forma destacada as descrições.

Já fora mencionado, e Reid o ratifica na quinta seção de EIP IV.i, que a concepção das coisas individuais aparece em graus, "forte e viva" ou "fraca e lânguida". Essas são qualidades de concepções das quais todo sujeito cognoscente tem consciência. À vivacidade e força, e seus contrários, podem ligar-se outras qualidades como "agradável" e "desagradável", ou mais simplesmente emoções opostas, que, presentes, dão maior ou menor vivacidade, em sentido positivo ou negativo. Por certo, uma concepção "viva" é respectiva comumente a objetos familiares; no caso humano, as concepções de objetos visíveis são em geral "as mais vívidas". De fato, vívidas, além de distintas, só as concepções de coisas individuais podem ser (sejam elas imaginadas ou reais), não as abstratas ${ }^{56}$. Importante, na progressão de EIP IV, é a afirmação de que as concepções de coisas "podem ser claras, distintas e firmes", ou então "obscuras, indistintas e inconstantes". Em especial, nota-se que Reid concede, tacitamente, que há uma passagem natural de tipos de concepção para tipos de juízo, de modo que o caráter (claro), distinto e firme de uma concepção naturalmente capacita a um juízo correto ${ }^{57}$, além disso, ao que Reid chama de "perspicuidade" na expressão de opiniões, na escolha de palavras, na composição das sentenças e na organização de um discurso em seu todo. Há, pois, uma relação natural entre concepção distinta, juízo correto e prova válida ${ }^{58}$.

Com efeito, quando se concebe um objeto, os "ingredientes" da concepção são ou as coisas com as quais se tinha familiaridade através de outro poder original da mente ou as partes e os atributos das coisas respectivas - para conceber "obrigação moral", "certo" e "errado", é preciso ter consciência (moral); para conceber qualidades secundárias como "cor" e "som", é preciso, dada a constituição humana, fazer uso dos sentidos. Os ingredientes simples da concepção são sempre estruturados e trazidos ao conhecimento pela "Natureza", por meio de outra faculdade que não a imaginação. Assim, concepções simples são recebidas pelos poderes humanos a partir da Natureza mesma - a imaginação precisa da recepção de qualidades primárias e secundárias, nada podendo criar senão a partir do que recebe na qualidade de "ingredientes" ou

56 Cf. EIP IV.i, p. 305-306.

57 Cf. EIP IV.i, p. 306. No mesmo contexto, Reid afirma que apreensão clara e firme e juízo são talentos que sempre caminham juntos, o segundo como companhia inseparável do primeiro. Cf. também Keith Lehrer, Thomas Reid, p. 131-132.

58 Cf. EIP IV.i, p. 306-307. 
"concepções simples", ainda que essas não sejam aquelas que são apresentadas, originariamente, de forma imediata pela "Natureza" 59. Necessita-se de tempo e análise para distinguir - em verdade, abstrair no sentido de separar de outros aspectos ou de um todo - atributos e relações dos objetos da natureza, discriminando-os e, então, denominando-os sob significado específico para a comunicação e o uso linguístico geral ${ }^{60}$. As concepções mais simples não são de um objeto na natureza, mas de "algum atributo ou [de alguma] relação singular de tais objetos"61. Ao que tudo indica, a coisa que a Natureza traz ao sujeito cognoscente é concebida como um corpo, algo com tal e tal propriedade primária e/ou secundária. Trata-se de um corpo extenso, em três dimensões, e sólido - e noções como "extensão", "solidez", "espaço", "ponto", "superfície", etc., são mais simples que a própria noção de "corpo". No entanto, a concepção de um "corpo" é sempre feita a partir desses elementos ${ }^{62}$. De todo modo, concepções de corpos são analisáveis e estão restritas aos ingredientes já ditos, mas a imaginação, ainda que dependa da recepção de corpos analisáveis nesses ingredientes, portanto, de concepções reais, pode formar infinda variedade de objetos inexistentes ${ }^{63}$.

A partir disso, é compreensível que Reid termine a sua análise das propriedades da concepção ressaltando que ela não se aplica só àquilo que têm existência - ela pode ser de um "cavalo alado" como pode ser de um "ser humano real" que foi visto, sem que haja confusão sobre o juízo de existência a ser gerado ou não. As operações da mente que, no decorrer dos Ensaios, antecedem o tratamento da concepção, são empregadas sobre o que é ou foi real, levando à crença na existência real de seus objetos - sensação, percepção, memória e consciência. A concepção pode ser relativa ao que não existe, não existiu e não existirá. Em resumo: a concepção é um ato mental e diz respeito a um objeto, existente ou não; ela supõe um sujeito cognoscente e tem termo em um objeto distinto do ato mental. Neste estudo importa, é claro, a concepção com a qual a percepção pode concorrer, de coisas reais do mundo exterior. Ao conceber, a mente tem ou pode ter como termo objetos materiais do mundo exterior, ela termina ou pode terminar em objetos imaginários. Em um e outro caso, ela não se vincula com "ideias" ${ }^{64}$.

59 Cf. EIP IV.i, p. 308-309.

60 Sobre a relação entre concepção de coisas individuais, abstração e generalização, cf. Keith Lehrer, Reid on Evidence and Conception, in: Malvin Dalgarno and Eric Matthews (eds.), op. cit., p. 131-139.

61 Cf. EIP IV.i, p. 309.

62 Cf. EIP IV.i, p. 309-310.

63 Cf. EIP IV.i, p. 310.

${ }^{64}$ Cf. EIP IV.i, p. 310-311. 


\section{A relação entre mente e mundo exterior}

É em especial a concepção de "coisas individuais", em percepções, que ajuda a entender qual pode ser a relação entre mente e mundo exterior: como do mundo exterior há conhecimento objetivo por parte de uma mente. Há aspectos surpreendentes no relato de Reid, e eles dizem respeito a como se concebe algo, quando se percebe algo. Afinal, pode-se entender a percepção como uma concepção de certo tipo que gera uma crença imediata sobre um objeto existente presente. Dela, a concepção é um componente natural; nela, a concepção é naturalmente - originalmente e a título de ganho de informação externa, ao menos - anterior ao perceber como tal. De que modo a mente tem relação com o mundo exterior, tal que o ato mental é respectivo diretamente à realidade, e o conteúdo dele, então, não é mental? A resposta básica a essa pergunta pode ser achada no Capítulo XIV de EIP II, "Reflexões sobre a teoria comum das ideias", e ainda em passagens do Capítulo II de EIP IV, "Teorias acerca da concepção".

Em EIP.xiv, primeira reflexão a ser feita é que não há dúvida de que os objetos que um ser humano percebe ("vê", por exemplo) enquanto objetos do mundo exterior estão diante de si, mas não as "ideias", de forma que o conhecimento dos objetos do mundo exterior não depende nem precisa ser inferido do conhecimento da existência das ideias como objetos imediatos na mente ${ }^{65}$. Em boa medida, isso diz respeito à concepção como parte da percepção. Mas, o ponto especialmente importante sobre a relação entre a mente e o mundo material exterior aparece ao longo da segunda reflexão acerca da teoria comum das ideias, que assevera que autores que a defenderam tomaram por garantida a sua existência, sem ter de prová-la e sem pô-la em questão ${ }^{66}$. Locke deu forma a essa convicção, quando afirmou que a ideia é o "objeto imediato do pensamento", tal que todos estariam convencidos da sua existência na mente por estarem conscientes disso. Dado que Reid insistirá que cada um está consciente das operações da mente, mas jamais que os seus objetos são "ideias" ou "imagens" 67 , é natural que se investigue, então, o seguinte ponto: se o caminho para avaliar a objetividade do pensamento não está em uma relação causal-intencional entre coisa e ideia, entre mundo material e ideia na mente, o que "causa" o pensamento objetivo, diga-se, o pensamento à medida que ele diz o mundo em seus aspectos (mais) fundamentais? Afinal, a epistemologia de Reid admite a tese de um realismo (direto) nos atos intelectuais, em especial, o de perceber.

65 Cf. EIP II.xiv, p. 172s.

${ }^{66}$ Cf. Philip de Bary, Thomas Reid and Scepticism. His Reliabilist Response. p. 96-101.

67 Cf. EIP II.xiv, p. 174s. 
Reid discute uma dada reflexão, em que se toma como necessário admitir, quando há uma percepção - e, assim, uma concepção da coisa do mundo exterior -, a validade de uma de duas teses: (i) os objetos agem sobre o agente humano ou (ii) os agentes humanos agem sobre os objetos ${ }^{68}$. No contexto disso estava a nota de Reid de que diferentes pessoas conseguem perceber os mesmos objetos reais que outra pessoa percebe, e isso não se explicaria se os seus objetos fossem diretamente "ideias" na mente. A partir daí, Reid menciona e rebate brevemente as opiniões de John Norris - em sua Theory of the Ideal or Intelligible World ${ }^{69}$ -, que dera resposta negativa à pergunta "Se as coisas materiais podem ser percebidas por nós imediatamente?". Aponta-se também para uma posição expressa por Samuel Clarke, para quem a alma só pode perceber coisas na presença das imagens das coisas percebidas. Substâncias como o ser humano (ao menos) percebem por estarem presentes às imagens das coisas; assim, a alma está presente às coisas no seu "sensorium"70. Aqui, o parecer a favor da percepção mediada por ideias é erguido sobre reflexões acerca da relação mente e mundo material, no sentido de ser essa, na prática, inexplicável sem a mediação "imagética". Outra posição enfática é a de William Porterfield ${ }^{71}$, que elabora uma teoria fisiológica, supostamente descritiva, da percepção. Confessando ignorância sobre como corpos agem sobre a mente, e ela sobre corpos, Porterfield defendeu que a mente só percebe as suas próprias modificações, "os estados diversos do sensorium", pois é a esses estados que ela está presente. Se o sujeito percebe a lua, percebe em verdade a sua representação impressa no sensorium, não a coisa em si. Porterfield ignora como a alma vê tais imagens ou recebe ideias a partir do sensorium ${ }^{72}$. Centrando-se em argumentos, Reid acha um princípio comum a Clarke e Porterfield (tomado de Clarke): "nada pode agir, ou sofrer ação, quando não está presente

68 Cf. EIP II.xiv, p. 176.

69 John Norris (1657-1711), filósofo inglês, deu continuidade ao projeto cartesiano e expandiu teses (teístas e metafísicas) de Malebranche, em particular no seu opus magnum (título citado no texto principal), cujos volumes I e II foram publicados, respectivamente, em 1701 e 1704.

70 Cf. EIP II.xiv, p. 175.

${ }^{71}$ Reid faz referência a "An Essay Concerning the Motions of the Eyes", in: Medical Essays and Observations, trabalho publicado em 1752, em Edimburgo. O Dr. William Porterfield (ca. 1696-1771) pertenceu a um conjunto de intelectuais que pesquisava a visão sobretudo no contexto da medicina, aplicando a esse campo certos aspectos da óptica física; a fronteira entre as especulações no campo da medicina e da filosofia era, nesse caso, de fácil travessia. Cf. também Nicholas J. Wade, Destined for Distinguished Oblivion - The Scientific Vision of William Charles Wells (1757-1817), p. 41. Sobre a recepção, por Reid, da teoria da visão de Porterfield, cf. também Norman Daniels, Thomas Reid's 'Inquiry'. The Geometry of Visibles and the Case for Realism, p. 41-46, 98-99.

72 Cf. EIP II.xiv, p. 176. 
mais do que o pode ali onde não existe". Reid admite que nada pode agir imediatamente ali onde não existe, seguindo-se disso que nada pode sofrer ação imediata onde um agente é ausente. Mas, o raciocínio seria conclusivo só se - e aqui Reid dá expressão a como Clarke e Porterfield interpretariam tal princípio -, "quando percebemos objetos", ou a tese (i) ou a tese (ii) é verdadeira.

Reid afirma com vigor que nenhuma das teses (i) e (ii) é auto-evidente e nenhuma delas tem como receber uma prova consistente. Com isso, o realismo de Reid, no conhecimento perceptual, tem explicitado o pano de fundo sobre qual é e pode ser a relação direta entre o entendimento ou o sujeito cognoscente e o mundo exterior. Consegue-se rejeitar (i) e (ii), primeiramente, por causa de uma gramática bem definida para aquilo que significa uma coisa agir sobre outra coisa. Isso significa que uma "força" ou um "poder" é exercido por um agente "que produz ou tem uma tendência a produzir uma mudança na coisa que sofre a ação"73. O último ponto é importante, isto é, que esteja na mente ou no objeto o sofrer mudança ao sofrer a ação: ora, na empiria e na anatomia da mente, essa mudança produzida ou sofrida simplesmente não é verificável.

Assim, inicialmente, Reid recusa com severidade a ideia de que o objeto percebido age nesses termos, portanto, modifica a mente. Em um exemplo típico ao professor ou ao recluso, a parede da sala que eu percebo com o auxílio dos olhos não age sobre a minha mente e, nesses termos, não é um agente: é inativa. Para um objeto, "ser percebido" não passa de uma "denominação externa": (a) o objeto não é ativo e (b) o objeto não sofre uma ação (cf. logo abaixo). Portanto, que o ato de perceber, concebendo algo e crendo de forma imediata que ele assim existe, não é descritível como uma relação de causa e efeito que tem como modelo as relações de causa e efeito entre os corpos. Em verdade, antes de buscar elucidar qual é então o vínculo entre o mundo exterior e a mente quando da percepção-cum-concepção, Reid justifica de onde é tirado o modelo mesmo que, sob um escrutínio mais adequado, simplesmente não poderia ser aplicado a esse domínio ${ }^{74}$.

Em geral, está-se preso à tendência de fazer analogias entre o movimento do pensar (mente) e o dos corpos (matéria). Um corpo é movido quando sofre a ação por outro corpo, e nisso há uma contiguidade ou uma tangência entre os corpos; esse tipo de movimento, impulso, toque contíguo, etc., a mente não recebe do objeto - os órgãos sensórios por certo o recebem diretamente, afinal, aqui está a ocorrência original do que se pode querer dizer com "impressão sensória"; o cérebro por certo o

${ }^{73}$ Cf. EIP II.xiv, p. 176.

74 Cf. EIP II.xiv, p. 177. 
recebe de modo indireto, mas a mente como tal não o recebe. Ora, entre o cérebro como fronteira do material e a mente como início de um novo tipo de realidade, não há relação de movimento, contiguidade ou tangência. Raciocínios por analogia, aqui, são vistos com suspeita. As propriedades dos corpos não são aptas a caracterizar e entender a mente ${ }^{75}$.

Em segundo lugar, Reid recusa a visão de que a mente age sobre o objeto que, ao perceber, ela concebe e em cuja existência crê. "Perceber um objeto" e "agir sobre um objeto" não são categorias equivalentes, o primeiro não é um caso do segundo. Se ser um agente é ter o poder de causar mudança em algo, como antes foi definido, de fato eu não ajo sobre a parede de minha sala quando a vejo. Fazendo uso da distinção - já mencionada acima, na Seção 2 - entre dois tipos de atos, a saber, os atos "imanentes", que ficam no poder que os produz, e os atos "transitivos", que saem do poder que os produz e chegam a um termo diferente dessa produção, o correto é dizer que as operações da mente são todas atos imanentes: "elas não produzem nenhum efeito sobre qualquer objeto exterior", de maneira que "pensar em um objeto" e "agir sobre um objeto" são tipologias de atos que não podem ser igualadas de maneira consistente $^{76}$.

É notável que, a partir da definição que Reid ofereceu para "agir sobre" e "sofrer a ação de", os seus pareceres sobre a relação objeto material e mente, na percepção-cum-concepção-e-juízo, insistem no critério de indícios empírico-introspectivos, em oposição à analogia adotada, para afirmar ali qualquer tipo de relação contígua do objeto com o sujeito percipiente. Essa acepção daquela relação permeia, de todo modo, as reflexões afins dos filósofos, em especial quando essas dizem respeito à mediação das "ideias". Não há evidência alguma para uma relação causal entre o objeto material exterior e a mente, quando da percepção, embora tenha de ser relatado - ao menos assumido - algum tipo de relação, para que se explique o caráter tanto real quanto objetivo da simples percepção de algo do mundo exterior. Como já foi dito, é claro que há contiguidade, na percepção, entre objeto e órgão sensório, de maneira que essa é justamente a "impressão": "uma impressão supõe contiguidade". Mas, embora esse aspecto, dada a constituição da natureza cognitiva humana como ela é agora, seja um pressuposto para a ocorrência natural da operação mental, essa última em si mesma não é uma impressão, um sentimento ou algo a ser compreendido pelas analogias do tato. Ora, é sabido que - não necessariamente como e por que - mediante algum mecanismo a impressão, ela mesma concausada

75 Cf. EIP II.xiv, p. 177.

${ }^{76}$ Cf. EIP II.xiv, p. 177s. 
pelo objeto, chega até a mente recipiente. Aqui, porém, pelo objeto, não há um "toque" contíguo na mente, nem direto nem indireto. A correção teórica - ao menos a liberdade do erro -, nesse caso da relação sujeito e mundo, pode atingir quem faz a separação entre a influência enganosa do raciocínio por analogia e a devida contemplação das operações mentais segundo o método científico ${ }^{77}$.

Mas, o que o filósofo do senso comum pode então afirmar, refletindo atentamente, sobre a relação mente e mundo material exterior, quando se trata da percepção de objetos? Reid faz uma confissão de ignorância ${ }^{78}$. Não se tem conhecimento de como a percepção é produzida na mente. É-se tão ignorante sobre isso como se é sobre "como fomos feitos". O poder de perceber é um poder constitutivo que fundamentalmente não se acessa ao ponto de descrever por completo. Ter-se-ia de concluir algo semelhante, caso a percepção fosse explicada sob a pressuposição de uma teoria das ideias, que seriam, a modo de imagens, os representantes dos objetos. Ora, a adoção dessa hipótese em nada facilita conhecer o processo de perceber. Uma imagem na mente, que representa o objeto, não altera a realidade de que "sabemos tão pouco como a percepção pode ser produzida por essa imagem quanto pelo mais distante objeto"79. A passagem tem, contudo, uma e outra dificuldade de interpretação. (1) A ineficiência da teoria das ideias em explicar a relação mente e mundo exterior, quando da percepção, é devida ao fato de que não se saberia como tal objeto imagético e representativo na mente, sendo supostamente contíguo ao objeto do mundo exterior, seria também contíguo à mente e nela causaria o ato de perceber? (2) Ou a ineficiência da teoria da ideias residiria na insolúvel dúvida sobre como saber, admitindo-se tais imagens, que elas são intencionais ou então contíguas aos objetos exteriores, porque objetivamente representantes deles?

Ao que parece, um pouco de cada um desses aspectos está incluído na (nova) crítica que Reid faz à teoria das ideias. Afinal, se descrever e provar uma contiguidade afim é algo irrealizável, mesmo a admissão, por hipótese, da existência de ideias na mente não realizaria o objetivo de uma teoria: não serviria para explicar como a percepção é possível. Ora, Reid justamente quer dizer que a teoria das ideias só tem força explicativa se conseguir justificar que, em seus termos, há uma explícita contiguidade entre mente e mundo exterior. Porém, ela não o faz, porque tal contiguidade, implícita na teoria das ideias, é inevidente. Que a

77 Cf. EIP II.xiv, p. 177-178. Cf. Roberto Hofmeister Pich, Thomas Reid, o método de filosofar e a rejeição do ceticismo, op. cit., subdivisões 1 e 3.

78 Cf. também Nicholas Wolterstorff, Thomas Reid and the Story of Epistemology, p. 258260.

${ }^{79}$ Cf. EIP II.xiv, p. 178. 
existência de ideias é inevidente, isso já fora constatado no decorrer dos Ensaios. Que, se admitida, a existência de ideias não explica como há percepção-cum-concepção-e-juízo, isso é asseverado em EIP II.xiv. Assim, também quanto ao que a teoria implicitamente assume sobre como o mundo material chega à mente, ela não explica fenômenos e fracassa novamente. O equívoco, nesse caso, é justamente a acepção infundada de que perceber, pela mente, depende de uma relação causal e de uma contiguidade entre itens diversos, como se esses fossem corpos do mundo material, ou seja, o objeto exterior, a ideia imagética e ainda a própria mente ${ }^{80}$.

Essa crítica na linha do fraco desempenho explicativo da teoria das ideias é expandida na quarta reflexão de EIP II.xiv. O seu próprio é o acento na tese de que as ideias não tornam nenhuma das operações da mente mais bem entendida ${ }^{81}$. A teoria das ideias traz confusão sobre como se percebe objetos distantes, como se imagina e como se tem lembranças. A dificuldade é que a teoria implica que todas as operações da mente se reduzem a uma só operação. A operação à qual todas se reduzem é "um tipo de sentimento, ou imediata percepção de coisas presentes, e em contato com o percipiente" 82 . Assim, tudo no pensar resume-se ao tanger, pela mente, um objeto (mental), contíguo a ela, sentido por ela, objeto que, por sua vez, presume-se contíguo ao objeto do mundo exterior. Reid chega dizer que assim como filósofos chegaram a afirmar que os sentidos humanos nada mais são do que modificações do tato, assim também as operações do entendimento humano se reduzem à percepção (à tangência) das ideias na mente ${ }^{83}$. Para Reid, esse "poder de perceber ideias" carece tanto de explicação quanto todos os poderes cognitivos que o pressupõem ou assumem. Supostamente pelo princípio metodológico de fazer uma "anatomia" da mente, em si esse "sentimento" ou essa "percepção imediata" é muito difícil de ser compreendida ${ }^{84}$. E igualmente difícil de compreender é o que se pretendeu explicar por meio disso: que alguém percebe objetivamente por causa da continuidade entre mente e ideia (objeto mental) tocada, e então entre ideia (objeto mental imediato) e objeto material exterior ${ }^{85}$.

A contiguidade mente-matéria e a teoria causal que a inclui, supostos trunfos da teoria das ideias, não podem ser verificadas e não explicam

80 Cf. EIP II.xiv, p. 178ss.

81 Cf. Philip de Bary, op. cit., p. 101-103.

82 Cf. EIP II.xiv, p. 185.

${ }^{83}$ Cf. EIP II.xiv, p. 185.

${ }^{84}$ Cf. Roberto Hofmeister Pich, Thomas Reid, o método de filosofar e a rejeição do ceticismo, op. cit., subdivisão 2 .

85 Cf. EIP II.xiv, p. 185. 
como a mente percebe. Reid, explicitamente, abre mão por completo de uma "teoria causal da percepção" 86 . Mas, como pode então ser explicado que a mente de fato percebe o mundo exterior? Qual pode ser então o modo como a mente, com a desejada e assumida objetividade, percebe o mundo exterior? Tudo o que Reid afirma sobre isso consiste em mostrar que o contato entre duas coisas não precisa ser a contiguidade, que responderia por tal "sentimento" ou "percepção" imediata da coisa na mente. Não há conexão necessária entre contiguidade e percepção, e qualquer movimento a favor disso aposta na ilusória semelhança entre mente e corpo, bem como na suposição de que "o objeto age sobre a mente, ou a mente sobre o objeto" ${ }^{87}$. Obviamente, mente e objeto exterior estão em relação. Portanto, é certo que há, no percipiente, "um poder de sentir ou de perceber". Porém, pelo método descritivo, o modo como esse poder é produzido e o modo como opera, os seus elementos e o seu processo, não podem ser (perfeitamente) conhecidos, estão além do que se pode conhecer. Reiteradamente, Reid assume que todos esses poderes foram constituídos e concedidos pelo "Ente Divino" que criou a natureza ${ }^{88}$.

\section{Ratificações}

Em EIP IV.ii, "Teorias acerca da concepção", a abordagem sobre a relação mente e mundo exterior material, quando operações cognitivas respectivas a esse campo objetivo estão em pauta, ganha confirmação. Reid reitera que, também para a concepção, a teoria das ideias foi amplamente aplicada - e nisso observam-se antigas pré-concepções comuns aos filósofos que, "por analogia", contribuíram para a formulação daquela teoria. Justamente a primeira "pré-concepção" é a de que, nos atos mentais, deve haver um "intercurso imediato entre a mente e o seu objeto", no sentido de que um item deve agir sobre o outro. A segunda pré-concepção reza que nas operações mentais há um "objeto do pensamento que realmente existe enquanto pensamos nele". Ambas estão vinculadas, e, na réplica de Reid, isso é bem salientado ${ }^{89}$.

Quanto ao primeiro preconceito, Reid entende que ele levou filósofos a crer que, dado que os objetos do mundo exterior são por demais distantes para agir sobre a mente de modo imediato, tem de haver

${ }^{86}$ Cf. Aaron Ben-Zeev, Reid's Opposition to the Theory of Ideas, in: Melvin Dalgarno and Eric Matthews (eds.), The Philosophy of Thomas Reid, p. 93-94.

87 Cf. EIP II.xiv, p. 185.

88 Cf. EIP II.xiv, p. 185. Cf. também Michel Malherbe, Thomas Reid on the Five Senses, in: Malvin Dalgarno and Eric Matthews (eds.), The Philosophy of Thomas Reid, p. 110ss.

${ }^{89}$ Cf. EIP IV.ii, p. 311-312. 
uma imagem sua presente à mente, sendo essa - a ideia - "o objeto imediato da percepção". Porque para responder a isso Reid faz menção de EIP II.xiv, cabe apenas notar ainda uma crítica adicional à assunção de tais imagens imediatas. Essencialmente, não há mais motivos para crer que a mente tem "um objeto imediatamente presente" ao realizar operações intelectuais do que há para crer que ela tem um objeto afim ao ter "afecções e paixões". Sujeitos mentais têm amor ou ressentimento, estima ou rejeição a pessoas e acontecimentos ligados a elas, mas não se advoga que "ideias" são os objetos imediatos desses sentimentos, e não as próprias pessoas. Elas estão tão longe da posição de objeto imediato da mente quanto os objetos materiais exteriores, quanto mais naqueles casos de pessoas que não existem mais no mundo ao redor do sujeito das afecções ${ }^{90}$.

Já a segunda pré-concepção entra em conflito com uma tese sobre a concepção, a saber, a de que é possível ter "concepção distinta de coisas que nunca existiram". Reid conhece o vasto e antigo partido filosófico que defende que sempre há um "objeto imediato" à mente, que realmente existe, mesmo que o "objeto remoto" (no mundo exterior) não exista. Para haver pensamento, é preciso haver um objeto existente. A ideia na mente garante a possibilidade do pensamento. Sem dúvida, a segunda pré-concepção é assumida pela - e é condição necessária da - primeira: fosse a segunda falsa, a primeira o seria também. Reid enuncia isso do seguinte modo: "se podemos conceber objetos que não têm nenhuma existência, segue-se que pode haver objetos de pensamento que nem agem sobre a mente, nem sofrem ação por ela, porque aquilo que não tem nenhuma existência não pode nem agir nem pode sofrer ação". Assim, a prova da falsidade da segunda pré-concepção é um recurso interessante para rejeitar a tese de que, estritamente falando, a mente age sobre o objeto, e o objeto age sobre a mente. A tese, pois, aqui apenas sobre a concepção, a saber, que o objeto da concepção pode ser algo que jamais existiu, que, portanto, a concepção de algo não dá em si presunção da existência da coisa concebida, critica a uma só vez a teoria das ideias, pois assevera que não há a ideia como objeto imediato de toda e qualquer operação da mente, e a tese da contiguidade entre mundo exterior e mente pela mediação mesma da ideia intencional ${ }^{91}$.

Dadas as duas pré-concepções, filósofos - contrariamente àquilo em que o vulgo e o filósofo do senso comum crêem - asseveram que em todo ato das operações percepção, concepção e memória existem dois objetos, um imediato, a ideia, outro mediato, o objeto "externo". Mas,

90 Cf. EIP IV.ii, p. 312-313.

91 Cf. EIP IV.ii, p. 313ss. 
se os dois princípios permitem construir toda a teoria das ideias em sua essência, e se fracassam, uma vez que é mostrado que são meras préconcepções fundadas em analogia, todo o sistema da teoria comum das ideias também fracassa ${ }^{92}$.

Em EIP IV.ii, Reid faz uma revisão da sustentação dos dois princípios na história da filosofia. Ela não será refeita aqui. O mais importante, porém, é que essa revisão permitirá ver que os ditos princípios são "conclusões apressadas", mais exatamente, "tiradas de uma suposta analogia entre matéria e mente". A crítica a esse argumento por analogia servirá de novo para substanciar a relação mente e mundo exterior para Reid. Afinal, para explicar as operações da mente os filósofos se valeram da constatação de que em outras operações há (i) o agente e (ii) a coisa sobre a qual se age. Por analogia, concluíram que a mesma estrutura operacional é válida para a mente. No caso, a relação entre mente e operações é análoga à relação entre "um homem e a sua obra". Querendo saber como as "obras da mente" são produzidas, os filósofos encontram nas "ideias" os seus "materiais". Assim, a noção de fundo é que tudo o que é produzido é produzido de alguma coisa, "do nada, nada é produzido". Reid acredita que algum raciocínio desse tipo está na raiz da teoria filosófica das ideias, e isso desde os pitagóricos e Platão ${ }^{93}$.

Apesar de as críticas de Reid a esses sistemas antigos serem em alguns casos sutis, serão deixadas de lado aqui ${ }^{94}$. Sem dúvida, Reid está consciente de que Aristóteles rejeitou a teoria das ideias, apesar de reter em seu sistema a pré-concepção de fundo, de a mente, para operar, precisar de "materiais", e nesses termos os objetos precípuos e necessários do intelecto são para ele as "espécies inteligíveis", nomeadas por Reid na terminologia escolástica. Reid percebe que a terminologia latina de species ou forma, para traduzir a noção aristotélica, cunhou o sentido dessas expressões nas línguas modernas ${ }^{95}$. Em resumo, o sistema de Aristóteles, que admite espécies inteligíveis e phantasmata, e igualmente o sistema platônico se fundam no princípio de que em todo pensar, em toda operação da mente, há alguma coisa sobre o que agir não importa se chamada de "ideia" ou de "espécie". Nos dois sistemas, (a) tomou-se como impossível que a Deidade fizesse o mundo sem matéria sobre a qual agir e (b) que um "Ente [ente?] inteligente" concebesse

92 Cf. EIP IV.ii, p. 313-314. De resto, é reconhecido que um dos mecanismos mais eficazes, segundo Reid, para criticar o cético será mostrar que os seus princípios epistêmicos estão ligados a uma "teoria da mente" repleta de equívocos, ou seja, justamente "the Way of Ideas"; cf. René van Woudenberg, Reid and Kant against the Sceptic, in: Joseph Houston (ed.), Thomas Reid. Context, Influence and Significance, p. 163ss.

${ }^{93}$ Cf. EIP IV.ii, p. 314-315.

94 Cf. EIP IV.ii, p. 315-319.

95 Cf. EIP IV.ii, p. 319. 
"alguma coisa que não existia", a menos que isso ocorresse "por meio de um modelo que realmente existia" ${ }^{96}$. Dos filósofos modernos Reid afirma que estiveram sempre convencidos de que há objetos imediatos à mente e eles em comum foram chamados de "ideias". Pode haver dissenso sobre sua natureza e forma de existir, mas há unanimidade quanto à existência das mesmas sempre que a mente está atuando ${ }^{97}$.

Os pareceres críticos que seguem em EIP IV.ii em verdade já tinham sido atingidos nos Ensaios. Assim, (i) a "surpresa" sobre a não-existência de ideias ocorre porque a ambiguidade da palavra "idea" (em inglês) não é notada. Ora, ela, na língua inglesa, guarda também o significado de "pensamento", "operação mental de pensar", sentido que é correto mesmo depois da revisão filosófica, gerando um entendimento em que não é possível pensar sem "ideias", se "ideias" significam "pensamentos". Os filósofos, entretanto, (ii) erradamente pensam que "ideia" não é pensamento, mas é "objeto do pensamento" que existe e é imediatamente notado pela mente. O decisivo, para rejeitar em conjunto as ditas préconcepções, é responder à pergunta se é uma contradição dizer que alguém "pode pensar em um objeto que não existe". Reid entende que isso é perfeitamente possível, e assim a segunda e, depois, a primeira pré-concepção são derrubadas. Prova-se que se pode pensar o que não existe fazendo uma apreciação metódica e empírica. Ora, consigo pensar ou conceber um "centauro", e estou consciente de fazê-lo. O objeto da concepção é um objeto que jamais existiu. Se o filósofo dissesse que preciso da "ideia" do centauro, a colocação é inócua, se isso quer dizer que preciso ter um pensamento. Se quer dizer que preciso de um objeto mental imediato, da imagem da coisa chamada "centauro", tal que o centauro eidético é o objeto "remoto" daquela concepção, isso, pela metodologia de Reid, não se comprova ${ }^{98}$.

O que se pode dizer sobre "concepção" e "ideias", finalmente? (a) Primeiramente, que não há dois objetos na concepção, mas um só, que é imediato à mente; (b) o objeto não é imagem, no caso do centauro, imagem desse animal, mas o animal mesmo, como um corpo com figura, cor, vida e movimento espontâneo; (c) em terceiro lugar, não se sabe como a ideia pode ser objeto do pensamento, pois nem sequer se concebe o que ela significa. Sem dúvida, a posse de uma imagem distinta na mente de um "centauro" pode consistir em uma concepção distinta - um ato justamente chamado de "imaginação". Mas, não é preciso, a partir daí, entender que há realmente imagem na mente, distinta da operação de

96 Cf. EIP IV.ii, p. 320.

97 Cf. EIP IV.ii, p. 321.

98 Cf. EIP IV.ii, p. 321-322. Cf. também Roger Gallie, Thomas Reid and 'The Way of Ideas', p. 108ss.; Philip de Bary, op. cit., p. 100-101. 
conceber o objeto - essa é a analogia envolvente, mas inútil, de crer que os atos em si precisam de uma imagem, não só de um objeto, para que sejam possíveis. A chave para obter clareza é, novamente, atentar para o que a consciência reflexiva revela sobre a mente. Por essa, sabe-se que só se tem consciência de vários modos de pensamento. Se esses são a "ideia", nenhuma objeção será feita. Se "ideia" é o objeto do pensamento, como imagem na mente, não se entende como isso pode ser achado na natureza. Se assim fosse, a sua existência deveria ser evidente, mas com efeito não é99.

Para rejeitar a tese de que o pensamento exige a existência de "ideias" como de "materiais" sobre os quais agir, pode-se também lembrar que a ideia de um "círculo" é a concepção do círculo; o objeto imediato dessa concepção é um círculo, e esse não está em lugar algum, pois é um universal, que não tem existência e não está em nenhum lugar. A concepção dele está na mente, é um ato mental, mas não é o caso que a coisa é na mente - essa é uma expressão figurativa sobre a concepção. Figurativamente, ter-se-ia a imagem de um círculo na mente, mas isso não deve ser visto em sentido literal. A concepção tem dois aspectos, a operação da mente e o objeto da concepção, a coisa concebida. Agora, se vista no segundo sentido, para Reid é óbvio que o objeto da concepção não é a imagem ou a semelhança do círculo, mas o círculo mesmo, não havendo imagem do círculo. A operação mesma de conceber o círculo não é imagem ou semelhança dele - pois seria comparar espécie de pensamento com espécie de círculo ${ }^{100}$.

A teoria das ideias na mente, na forma mesma daquelas duas pré-concepções, trabalha com ficções - assim o são as "espécies" ou "imagens" na mente e em contato com ela, bem como "ideias" na mente sempre como "ideias" de "coisas" que realmente existem. Ao desabonar a segunda pré-concepção, rejeita-se também a primeira, de maneira que, indiretamente, a tese da contiguidade mundo extramental, ideia e mente se dissolve ${ }^{101}$.

\section{Considerações finais}

Nos textos que tratam do tema da relação entre mente e mundo exterior, deve ser notado que Reid respeita severamente os seus

99 Cf. EIP IV.ii, p. 322-323. Rigorosamente, se existem "ideias", nada se pode saber além delas. Porque, se existem e como tais são objetos imediatos, jamais se poderá saber por raciocínio ou inferência da existência de outras coisas, com exceção, como Berkeley pensou, da existência de um "Autor inteligente delas".

${ }^{100}$ Cf. EIP IV.ii, p. 323-324.

${ }^{101}$ Cf. EIP IV.ii, p. 324. 
princípios metodológicos de análise da mente, a saber, os critérios de evidência e de peso explicativo. Conjeturas devem ser rejeitadas para que pareceres sobre a relação entre mente e corpo, entre sistema mental e sistema material, sejam cientificamente oferecidos. Nas passagens inspecionadas, Reid estabelece com detalhes que nada acerca da ação de objetos sobre a mente ou da mente sobre objetos pode ser posto por analogias do campo da relação causal entre corpos - nada nesse discurso é evidente a partir da investigação da mente, nenhuma prova respectiva a uma impressão contígua do objeto material sobre a mente pode ser validada. A mente não percebe a partir de um impulso ou toque do objeto, e na percepção tampouco a mente age sobre o objeto. Perceber um objeto e agir sobre ele são coisas totalmente diferentes. Descritivamente, pela anatomia da mente, Reid mostra isso suficientemente, (i) ao mostrar que atos mentais são sempre "imanentes", e não "transitivos" e (ii) ao desabonar a existência mesma de ideias como facilitadores e elementos explanadores daquela suposta contiguidade a modo de "tato" entre objeto e mente - melhor dizendo, entre o objeto exterior, a ideia na mente e a própria mente. Por certo, uma terceira acepção fundamental, implicitamente posta, para o parecer de Reid é (iii) o seu "dualismo"102, ou seja, a sua convicção de que existe o "mental" em diferença ontológica ao "material", em termos de eventos, propriedades e substâncias, tal que o mental é aquilo que só pode ser acessado por uma autoconsciência ou por uma consciência reflexiva ${ }^{103}$. Creio que é uma tese verdadeira sobre a natureza da mente, na acepção de Reid, que "O mental é aquilo que só pode ser termo de uma consciência reflexiva" - tese que não implica, é claro, que a mente só conhece o que é mental, mas que deve implicar, antes, que há eventos, propriedades e substâncias mentais. A quarta acepção fundamental, e novamente posta de maneira implícita, que norteia as convicções de Reid sobre a relação entre a mente e o mundo exterior é que (iv) "O mental como tal não pode ser causado (gerado) pelo material", pois o "material", sendo ontologicamente distinto, não pode, em alguma causação substancial, gerar o "mental".

Pondo de lado analogias e refletindo corretamente sobre a percepçãocum-concepção de objetos sensórios, o correto é dizer que, apesar da consciência reflexiva do ato de perceber e de uma argumentação válida acerca da natureza mental de seu sujeito, tem-se total ignorância sobre o modo como a percepção é produzida - se a pergunta a tratar-se é,

102 Cf. também Michel Malherbe, Thomas Reid on the Five Senses, in: Melvin Dalgarno and Eric Matthews (eds.), op. cit., p. 110ss. "Cartesiano" ou não, o dualismo de Reid bem se classifica como uma forma de dualismo de substância. Sobre isso, cf. também K. T. Maslin, Introdução à filosofia da mente, p. 39-71.

${ }^{103}$ Cf. EIP II.xiv, p. 177. 
portanto, sobre a constituição possível daquele vínculo estabelecido de dois relata metafisicamente distintos. Sobre o como da percepção sabe-se tão pouco quanto se sabe sobre como, de maneira definitiva (progressos da biologia evolucionária, da ciência cognitiva e da ciência do cérebro a parte), os próprios seres humanos foram feitos.

A meu juízo, Keith Lehrer apontou com correção que, segundo Thomas Reid, há uma lei da natureza, cuja explicação não é conhecida e é eventualmente incognoscível agora, pela qual as impressões físicas ocasionadas pelos objetos - e, pois, via órgãos sensórios, nervos e cérebro - são "conjugadas regularmente com a percepção". No sentido mínimo e inofensivo de "dar ocasião", pode-se dizer que objetos e impressões "causam" as percepções. Nesse caso, parece plausível afirmar, sem lesar o aspecto em boa medida espontâneo ou de todo modo "agencial" e não "eventual" dos juízos perceptuais ${ }^{104}$, que há entre objetos e impressões (ou inputs) vinculados a percepções-cum-concepções (ou outputs) "conjunções regulares", que possibilitam conhecimento primário de corpos com propriedades primárias e secundárias - e tais "conjunções regulares" são expressões de "leis da natureza". O quadro dualista assumido e até certo ponto justificado descritivamente por Reid é o de que a impressão sobre o órgão sensório deve ser tomada pelo agente das operações da mente como "instrumento" ou "ocasião" para perceber; porém, nem as impressões nem a sua conjunção regular com percepções são entendidas como necessárias. Essencial à percepção é o poder para tanto; perceber é, na sua essência, uma causação interna da parte do agente mental, não um efeito produzido a partir das impressões sensórias e dos objetos e recebido passivamente ${ }^{105}$.

${ }^{104}$ Cf. Roger D. Gallie, Thomas Reid: Ethics, Aesthetics and the Anatomy of the Self, p. 7-8.

${ }^{105}$ Cf. Keith Lehrer, Thomas Reid, p. 98-99. Sem dúvida, é um ponto controverso se Reid é bem sucedido, e suficientemente detalhado, no que tange à aplicação de sua versão das regras newtonianas do filosofar ao tópico da relação matéria e mente - e, pois, à defesa do papel ativo único da mente imaterial, na percepção. Cf. sobre isso Alan Tapper, Reid and Priestley on Method and the Mind, in: John Haldane and Stephen Reid (eds.), The Philosophy of Thomas Reid - A Collection of Essays, p. 104ss., 109ss., que expõe o problema na perspectiva da disputa de Reid com o materialismo de Joseph Priestley e da tese da passividade da matéria. Sobre a disputa de Reid com o materialismo de Priestley, cf. Paul Wood, Introduction, in: Paul Wood (ed.), Thomas Reid on the Animate Creation - Papers Relating to the Life Sciences, p. 30-56, e Thomas Reid, Part Three Materialism (Papers), in: Paul Wood (ed.), Thomas Reid on the Animate Creation - Papers Relating to the Life Sciences, p. 125-241. 
R.H. Pich - Thomas Reid sobre concepção, percepção e ...

\section{Referências}

\section{Fontes}

REID, Thomas. An Inquiry into the Human Mind on the Principles of Common Sense (1764). In: BROOKES, Derek R. (ed.). Thomas Reid - An Inquiry into the Human Mind on the Principles of Common Sense. A Critical Edition. Edinburgh: Edinburgh University Press, 2000 (paperback).

Essays on the Intellectual Powers of Man (1785). In: BROOKES, Derek R. Thomas

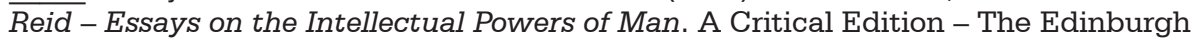
Edition of Thomas Reid. Annotations by Derek R. Brookes and Knud Haakonssen. Introduction by Knud Haakonssen. Pennsylvania: Pennsylvania State University Press, 2002.

Part Three - Materialism (Papers). In: WOOD, Paul (ed.). Thomas Reid on the Animate Creation - Papers Relating to the Life Sciences. University Park (Pennsylvania): The Pennsylvania State University Press, 1995, p. 125-241.

\section{Literatura secundária}

ALSTON, William P. Reid on Perception and Conception. In: DALGARNO, Melvin and MATTHEWS, Eric (eds.). The Philosophy of Thomas Reid. Dordrecht: Kluwer Academic Publishers, 1989, p. 35-47.

BARY, Philip de. Thomas Reid and Scepticism. His Reliabilist Response. London-New York: Routledge, 2002.

BEN-ZEEV, Aaron. Reid's Opposition to the Theory of Ideas. In: DALGARNO, Melvin and MATTHEWS, Eric (eds.). The Philosophy of Thomas Reid. Dordrecht: Kluwer Academic Publishers, 1989, p. 91-101.

BONJOUR, Laurence. Conhecimento do mundo exterior. In: BONJOUR, Laurence e BAKER, Ann (eds.). Filosofia - Textos fundamentais comentados. Porto Alegre: Artmed, 2010, p. 142-160.

DANIELS, Norman. Thomas Reid's 'Inquiry'. The Geometry of Visibles and the Case for Realism. With a New Afterword. Foreword by Hilary Putnam. Stanford: Stanford University Press, 1989 (orig. 1974).

GALLIE, Roger. Thomas Reid and 'The Way of Ideas'. Dordrecht-Boston-London: Kluwer Academic Publishers, 1989.

. Thomas Reid: Ethics, Aesthetics and the Anatomy of the Self. Dordrecht-BostonLondon: Kluwer Academic Publishers, 2010.

GRECO, John. Reid's Reply to the Skeptic. In: CUNEO, Terence and VAN WOUDENBERG, René (eds.). The Cambridge Companion to Thomas Reid. Cambridge, Cambridge University Press, 2004, p. 134-155.

HOLT, Dennis Charles. The Defense of Common Sense in Reid and Moore. In: DALGARNO, Melvin and MATTHEWS, Eric (eds.). The Philosophy of Thomas Reid. Dordrecht: Kluwer Academic Publishers, 1989, p. 145-157.

LEHRER, Keith. Reid on Evidence and Conception. In: DALGARNO, Melvin and MATTHEWS, Eric (eds.). The Philosophy of Thomas Reid. Dordrecht: Kluwer Academic Publishers, 1989, p. 121-144. 1989.

. Thomas Reid. London-New York: Routledge (The Arguments of the Philosophers), 
MALHERBE, Michel. Thomas Reid on the Five Senses. In: DALGARNO, Melvin and MATTHEWS, Eric (eds.). The Philosophy of Thomas Reid. Dordrecht: Kluwer Academic Publishers, 1989, p. 103-117.

MASLIN, K. T. Introdução à filosofia da mente. Porto Alegre: Artmed, 2009.

McKITRICK, Jennifer. Reid's Foundation for the Primary/Secondary Quality Distinction. In: The Philosophical Quarterly 52 (2002), p. 478-494.

MICHAUD, Yves. Reid's Attack on the Theory of Ideas: From a Reconsideration of Reid's Arguments to a Reassessment of the Theory of Ideas. In: DALGARNO, Melvin and MATTHEWS, Eric (eds.). The Philosophy of Thomas Reid. Dordrecht: Kluwer Academic Publishers, 1989, p. 9-34.

NICHOLAS, Ryan. Thomas Reid's Theory of Perception. Oxford: Clarendon Press, 2007.

PICH, Roberto Hofmeister. Thomas Reid, o método de filosofar e a rejeição do ceticismo. In: Dissertatio 32 (2010), p. 243-275.

TAPPER, Alan. Reid and Priestley on Method and the Mind. In: HALDANE, John and READ, Stephen (eds.). The Philosophy of Thomas Reid - A Collection of Essays. Oxford: Blackwell Publishing, 2003, p. 98-112.

VAN CLEVE, James. Reid's Theory of Perception. In: CUNEO, Terence and VAN WOUDENBERG, René (eds.). The Cambridge Companion to Thomas Reid. Cambridge: Cambridge University Press, 2004, p. 101-133.

VAN WOUDENBERG, René. Reid and Kant against the Sceptic. In: HOUSTON, Joseph (ed.). Thomas Reid. Context, Influence and Significance. Edinburgh: Dunedin Academic Press, 2004, p. 161-186.

WADE, Nicholas J. Destined for Distinguished Oblivion - The Scientific Vision of William Charles Wells (1757-1817). New York: Kluwer Academic - Plenum Publishers, 2003.

WOLTERSTORFF, Nicholas. Reid on Common Sense. In: CUNEO, Terence and VAN WOUDENBERG, René (eds.). The Cambridge Companion to Thomas Reid. Cambridge: Cambridge University Press, 2004, p. 77-100.

Press, 2001.

WOOD, Paul. Introduction. In: WOOD, Paul (ed.). Thomas Reid on the Animate Creation - Papers Relating to the Life Sciences. University Park (Pennsylvania): The Pennsylvania State University Press, 1995, p. 1-78. 